\title{
Warm Climate Production Guidelines for Agave ${ }^{1}$
}

\section{Dr. Rick Schoellhorn and Alexis A. Richardson ${ }^{2}$}

\section{Commercial Production of Agave}

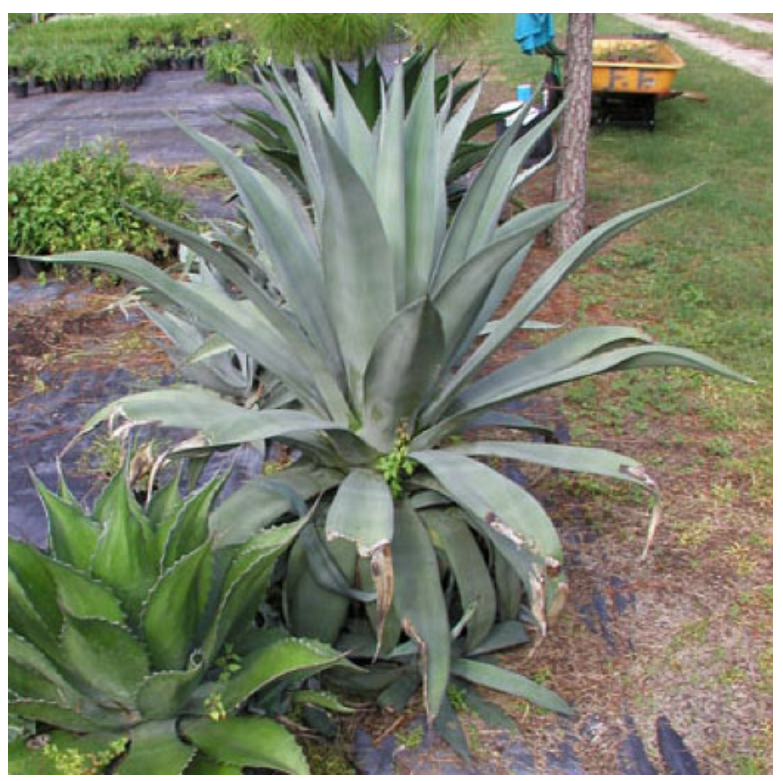

Figure 1. Agave americana and Agave ferox demonstrating the differences in foliage color seen in the Agave genus. Credits: Photo by Dr. Rick Schoellhorn.

The century plant, or Agave family, is an incredibly diverse group of rosette-forming perennials. Agave are available to suit almost every climate zone in the U.S. with cold hardy forms that can withstand single-digit temperatures. While most people look at these plants as a southwestern phenomenon, our changing ideas of what an annual is are opening markets for these plants as summer color throughout the U.S. Northern growers may need to look at buying the plants in pre-finished material, as the crop is in general a very slow one: from seed to sale can be 1-6 years. Plants are durable but heavy, which can be a problem in shipping. Another misconception is that all Agave are sharply spined and a problem to work with; while it may be true that most Agave are spined, one of the most dramatic and easily grown species, A. attenuata, is soft-leaved and extremely architectural. A. americana is a large, blue-gray foliaged form with sharp spines. It thrives in a wide range of climates across the southern half of the United States. The variegated form of this plant is less cold hardy, but broadly banded with creamy yellow stripes. There are Agave native throughout the U.S and for specimen containers, or creating a western look in a landscape you can't beat these prehistoric, bold-textured succulents, except perhaps by using paddle cacti, which is also a great idea, but that will have to be another article.

Agave and other succulent plants are increasingly popular among plant collectors, home gardeners, and professional landscapers for a number of reasons. With water restrictions in place in many areas across the country there is an increasing demand for plants that are appropriate for xeriscaping, or landscaping to

1. This document is ENH 992, one of a series of the Environmental Horticulture Department, Florida Cooperative Extension Service, Institute of Food and Agricultural Sciences, University of Florida. Original publication date November 9, 2004. Please visit the EDIS web site at http://edis.ifas.ufl.edu.

2. Rick Shoellhorn, associate professor, commercial floriculure specialist; Alexis A. Richardson, contributing writer; Environmental Horticulture Department, Institute of Food and Agricultural Sciences, University of Florida, Gainesville FL 32611.

The Institute of Food and Agricultural Sciences is an equal opportunity/affirmative action employer authorized to provide research, educational information and other services only to individuals and institutions that function without regard to race, color, sex, age, handicap, or national origin. For information on obtaining other extension publications, contact your county Cooperative Extension Service office. Florida Cooperative Extension Service/Institute of Food and Agricultural Sciences/University of Florida/Christine Taylor Waddill, Dean. 
promote water conservation. Many Agave are particularly well adapted to withstand climatic extremes, from drought to high heat, strong winds, and frost. They are generally free from insect pests and diseases and are less prone to nutrient deficiencies. They are also amazingly tolerant of poor and shallow soils. There is a huge variety of forms and landscape uses for Agave, including ground covers, bedding plants, and imposing garden centerpieces. Agave make excellent container plants, creating a high-value product that consumers love because they stand up to neglect and don't require frequent watering. Agave provide visual interest in the form of bold textures and colorful foliage.

Many of these characteristics make Agave attractive to professional growers. Although they may take longer to produce, these are plants that actually thrive on reduced water and fertilizer inputs. They rarely require insecticides, fungicides, or plant growth regulators. They are easily propagated by stem or leaf cuttings, while others readily produce offsets that can be removed and potted separately. Most succulents can also be propagated by seed, but it may take a year or longer for them to reach a saleable size.

In order to grow Agave, you will probably need to modify your normal production protocol. A well-aerated and freely draining medium is critical. Commercial cactus and succulent mixes usually consist of equal parts coarse sand, perlite, and peat or fine bark. If you want to make your own, try mixing one part soil-less or soil-based media with one part coarse sand and one part washed grit, small gravel, claimed clay, pumice, or expanded slate. Mixing a time-released fertilizer in the media will ensure a constant supply of nutrients. Agave should be allowed to dry slightly between waterings. Under-potting is a good way to ensure that the roots don't become oversaturated. To produce rapid growth and the best form and color, Agave should be grown in the strongest light possible. Plants that are grown in full sun and warm temperatures will respond more favorably to high water and fertilizer inputs. Many Agave tend to go dormant during the shorter days and cooler temperatures of winter. This is the time when they are most prone to fungal pathogens that cause rot. To keep them actively growing during the winter months, keep your greenhouse warm and consider extending day length with supplemental lighting. Maintaining a lower than normal relative humidity and excellent air circulation in your greenhouse will reduce the likelihood of disease and insect pests.

In general, this group of plants has always played a minor role in our industry, but with increasing water restrictions and consumers looking for the easiest way to get the maximum effect for their gardening efforts, you may want to brush up on your knowledge of Agave and other succulent-like plant materials. They offer a higher price point than traditional annuals and in some cases even perennials. They can be a local market item that allows you a niche that will likely never get truly exploited by chain retailers because these plants are problematic in the mass-market machinery. In addition, there are many native forms found throughout the United States and these plants can also give you or your retail customers the ecological identity our industry needs to promote.

If you're looking to diversify your product line and set yourself apart from the competition, perhaps you should consider growing succulents. These are plants that are adapted to withstand drought by storing water in specialized cells in their leaves, stems, and/or roots. The term succulent does not refer to a plant family per se, but to a water-storing adaptation that is found in many different plant families. Cacti are probably the best known family of succulent plants, but there are many other types of succulents in a huge variety of shapes and sizes.

\section{Commercial Production Guidelines for Agave}

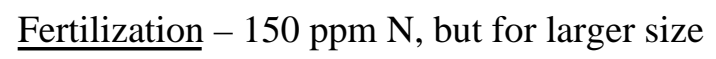
production, a granular or slow-release fertilizer can be applied at medium rates. When using slow-release fertilizer, make sure all other production environmental conditions are optimal, otherwise stem breakage, poor quality growth, and diseases can become an issue.

Watering - Agave prefer to be on the dry side. The key factor in good production is making sure roots have a lot of air surrounding them, which means 
you really need to watch watering and possibly use media designed for succulent production.

Media - Use media with a lot of drainage capacity. Many growers cut normal peat production media in half and supplement with scoria, gravel, or PermaTill $^{\circledR}$. However, you can use a standard production medium; you will just need to be careful with watering frequency.

Production Temperatures - In almost all cases quality growth occurs at night temperatures above $55^{\circ} \mathrm{F}$ and day time temperature must be at least $65-70^{\circ} \mathrm{F}$. However, the hot days of summer will not be a problem and production conditions into the $100 \mathrm{~F}$ range can still produce good quality plants. High temperatures and high humidity can create a lot of disease issues, so stay on the lookout.

Light level - The higher the better in most cases, a minimum of 5,000 ft-C. Most plants require high light to develop strong leaf coloration and will stretch badly under low light conditions. Low light levels can be offset somewhat with dry soil conditions, but only for a short period of time.

Propagation - Seed, cuttings, leaf cuttings, division of mature plantings.

Crop timing - Highly dependent on the crop. Check with your supplier and find out crop schedules before you commit to growing the crop. Some types are very slow and may require more than one season to reach a salable size. In general expect about a 10to 12-month crop cycle.

Growth regulators - In most cases you'll be using drought, and high light levels as a plant growth regulator and chemical PGRs should not be necessary.

Flowering - In most cases these plants do not need to be in flower to be sold; that's part of the inherent advantage of growing this type of crop. Within the different types of succulents we've discussed here there are long-day and short-day flowering types, so do some research before taking on the crop if flowering is a major issue.

Overall notes:
Care needs to be taken to avoid overwatering and overfertilizing any of these plants, especially during the short days, lower light levels, and cooler conditions of winter.

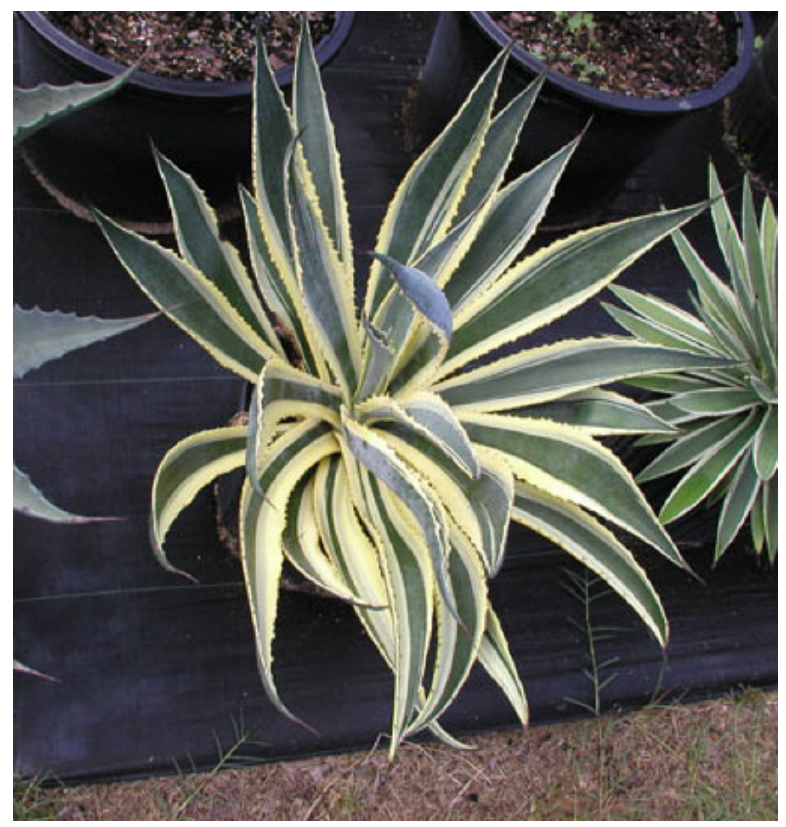

Figure 2. Agave americana Variegata is a larger (8- to 10-foot) form of this popular species. Credits: Photo by Dr. Rick Schoellhorn.

\section{Commercial Sources for Agave}

ForemostCo - http://www.foremostco.com

Ball Floraplant - http://www.ballfloraplant.com

Liner Farm Inc. - Box 701369, St. Cloud, FL 34770-1369, Phone: (800) 330-1484, Fax: (407) 892-3593

Plant Delights - http://www.plantdelights.com

Yucca Do Nursery - http://www.yuccado.com

Saul Nurseries Inc. - 5007 New Peachtree Rd, Chamblee GA 30341-3124, Phone 770-458-0058

Bodger Botanicals http://www.michells.com/Bodger/bodger.htm

Green Leaf Perennials http://www.green-leaf-ent.com

EuroAmerican Propagators http://www.euroamprop.com 


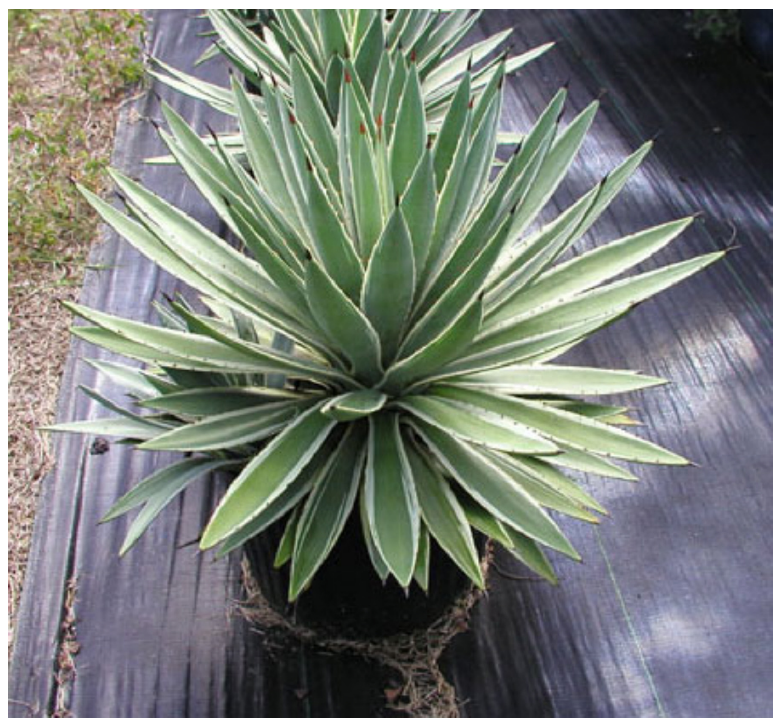

Figure 3. Agave angustifolia is a tropical species with little cold hardiness but fast growth within a season. Credits: Photo by Dr. Rick Schoellhorn. 